\title{
Comparison between different approaches to modeling shallow landslide susceptibility: a case history in Oltrepo Pavese, Northern Italy
}

\author{
D. Zizioli ${ }^{1}$, C. Meisina ${ }^{1}$, R. Valentino ${ }^{2}$, and L. Montrasio ${ }^{2}$ \\ ${ }^{1}$ Department of Earth and Environment Sciences, University of Pavia, Via Ferrata 1, 27100 Pavia, Italy \\ ${ }^{2}$ Department of Civil, Environmental, Territory Engineering and Architecture, University of Parma, Viale G. P. Usberti 181/A \\ 43100 Parma, Italy
}

Correspondence to: D. Zizioli (davide.zizioli@unipv.it)

Received: 6 September 2012 - Published in Nat. Hazards Earth Syst. Sci. Discuss.: Revised: 18 January 2013 - Accepted: 21 January 2013 - Published: 5 March 2013

\begin{abstract}
On the 27 and 28 April 2009, the area of Oltrepo Pavese in northern Italy was affected by a very intense rainfall event that caused a great number of shallow landslides. These instabilities occurred on slopes covered by vineyards or recently formed woodlands and caused damage to many roads and one human loss. Based on aerial photographs taken immediately after the event and field surveys, more than 1600 landslides were detected. After acquiring topographical data, geotechnical properties of the soils and land use, susceptibility analysis on a territorial scale was carried out. In particular, different physically based models were applied to two contiguous sites with the same geological context but different typologies and sizes of shallow landslides. This paper presents the comparison between the ex-post results obtained from the different approaches. On the basis of the observed landslide localizations, the accuracy of the different models was evaluated, and the significant results are highlighted.
\end{abstract}

\section{Introduction}

Rainfall-induced shallow landslides typically occur due to small failures of natural slopes that collapse catastrophically without warning. Although they generally involve small volumes of soil, due to their close proximity to urbanized areas, they cause significant damage to structures and infrastructure and, sometimes, human losses. Moreover, as a consequence of particularly intense and concentrated rainfall, they can be densely distributed across a territory.

The susceptibility analysis of rainfall-induced shallow landslides on a large scale is usually performed using statistical methods (Carrara et al., 1991; Bai et al., 2009; Cervi et al., 2010; Li et al., 2012). More recently, physically based models proved rather promising in evaluating shallow landslide spatial susceptibility, starting from a distributed slopestability analysis (Montgomery and Dietrich, 1994; Wu and Sidle, 1995; Iverson, 2000; Qiu et al., 2007; Baum et al., 2008; Lu and Godt, 2008; Simoni et al., 2008; Baum and Godt, 2010). Encouraged by the performance of these physically based models and with the aid of the widely available Geographic Information Systems (GIS), researchers developed and applied methods that appear suitable for determining both the timing and localization of shallow landslides in response to rainfall on a regional scale (Salciarini et al., 2006, 2008; Godt et al., 2008a, b; Schmidt et al., 2008; Apip et al., 2010; Liao et al., 2011; Vieira et al., 2010; Arnone et al., 2011). With regard to the spatial susceptibility assessment of shallow landslides, different methods of analysis are not mutually exclusive. On the contrary, the use of different strategies and the comparison of the obtained results can help to:

- Enhance the quality and reliability of each method.

- Highlight and identify the most important factors affecting the phenomenon.

- Omit less influential aspects to simplify the models. 
- Select the most appropriate methodology to achieve a specific goal.

For these reasons, it is useful to apply different analysis approaches to a well-documented case history, such as for the event that occurred in the area of Oltrepo Pavese (Lombardy Region, northern Italy) on the 27 and 28 April 2009. A particularly intense rainfall triggered a significant number of shallow landslides (approximately 1600), which, in turn, caused damage to many roads and one human loss. The rich landslide database, compiled on the basis of aerial photos and field surveys, was useful in evaluating the results of different deterministic models in terms of the correspondence between the landslides source area localization and the assessed unstable areas.

Four physically based stability models, namely TRIGRS (Transient Rainfall Infiltration and Grid-Based Regional Slope-Stability Model; Baum et al., 2008), SHALSTAB (Shallow Slope Stability Model; Montgomery and Dietrich, 1994), SINMAP (Stability Index Mapping; Tarboton, 1997; Pack et al., 1999) and SLIP (Shallow Landslides Instability Prediction; Montrasio, 2000; Montrasio and Valentino, 2008), were utilized to analyze the study area.

These physically based models are characterized by different levels of complexity, and their results strongly depend on the quality and detail of the input data. Moreover, their capability of providing reliable results within a reasonable computation time span is strictly linked to the extent of the study area.

Vegetation, land use and their change in time are widely recognized as important factors influencing rainfall-triggered landslides (Begueria, 2006a); therefore, the models were applied to two contiguous sites with the same geological context, but different land cover change, which results in different typologies and sizes of shallow landslides.

In the following section, the main qualities distinguishing the four models are outlined, and their predictive capabilities are evaluated using a quantitative method known as receiver operating characteristic, ROC (Begueria, 2006b). Finally, limits and key advantages of the different simulations are discussed, and comparisons between the obtained results are highlighted.

\section{The study area}

The study area is located in the northeastern sector of Oltrepo Pavese, where many shallow-seated landslides occurred due to rainfall on 27-28 April 2009 and which belongs to the northwestern Italian Apennines (Fig. 1).

Two test sites were selected on the Apenninic margin. Area 1, with a surface area of $13.36 \mathrm{~km}^{2}$, is characterized by a shallow landslide density of $\sim 37$ per square kilometer $(\sim 1.85 \%$ of the entire area). A second study area (area 2$)$, with an area of $10.6 \mathrm{~km}^{2}$, has the same geological characteristics as area 1 and experienced shallow landslides during the
April 2009 rainfall event $(\sim 24$ landslides per square kilometer, equal to approximately $0.5 \%$ of the entire area). However, the land cover is quite different between the two study areas; specifically, area 1 is characterized by vineyards and woodlands $(15 \%)$ that correspond to vineyards abandoned after the 1980s, and the land cover of area 2 is constituted only by vineyards that have not changed over the last thirty years.

The test site slopes are characterized by a medium-high gradient and are composed of marls (S. Agata Fossili Marls), gravel, sand and poorly cemented conglomerates (M. Arzolo Sandstones and Rocca Ticozzi Conglomerates). A small portion of the area is characterized by the presence of the Gessoso-Solfifera Formation (marls, sandy marls and vacuum limestone with lenses of gypsum-rudites containing gypsum selenite) (Fig. 1). The strata dip east-northeast. Colluvial soils, derived from the weathering of bedrock, have a thickness ranging from $0.5 \mathrm{~m}$ to 2 or $3 \mathrm{~m}$ at the bottom of the valleys.

The climatic regime in the area is the ApennineMediterranean type, characterized by dry summers and cold winters, with a primary peak of rainfall in autumn and a secondary peak in spring. The mean annual temperature is $12^{\circ} \mathrm{C}$. The average annual rainfall is approximately $700 \mathrm{~mm}$ in low-lying areas and $998 \mathrm{~mm}$ in the hills, with an increase in the rainfall amount from west to east.

Oltrepo Pavese is characterized by high density of landslides. The mass movements often develop in clayey-marly formations and are classified as complex deep movements triggered by prolonged rainfalls. More recently climate changes are responsible of extreme weather conditions, such as heavy rainfalls, that have triggered shallow landslides. The event of April 2009 was the only documented case of rainfallinduced shallow landslides that hit the Oltrepo Pavese since the fifties.

On the 27 and 28 April 2009, the northeastern sector of Oltrepo Pavese experienced an extreme rainfall event. On the 28 April, the Cigognola rain-gauge station recorded $150 \mathrm{~mm}$ of rain in $48 \mathrm{~h}$ ( $20 \%$ of the annual average amount), with a maximum rainfall intensity of $22 \mathrm{~mm} \mathrm{~h}^{-1}$ at 9 p.m. on 27 April (Fig. 2).

After this peak was reached, several shallow landslides were triggered, causing one fatality and loss of agricultural land, as well as damaging/blocking roads in several places. The April 2009 event occurred after a rather wet winter season with heavy snowfall. 


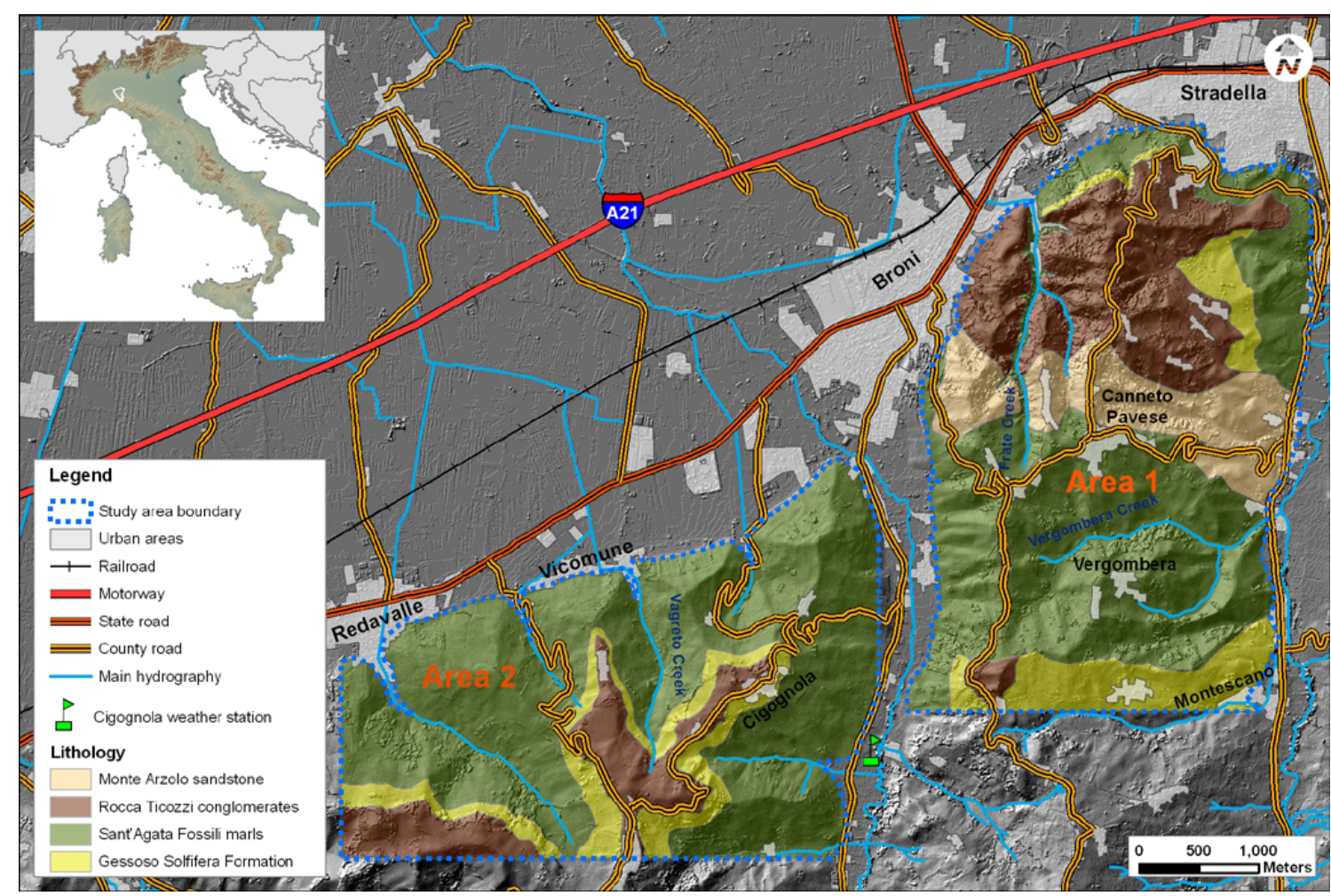

Fig. 1. Geological map of the study area.

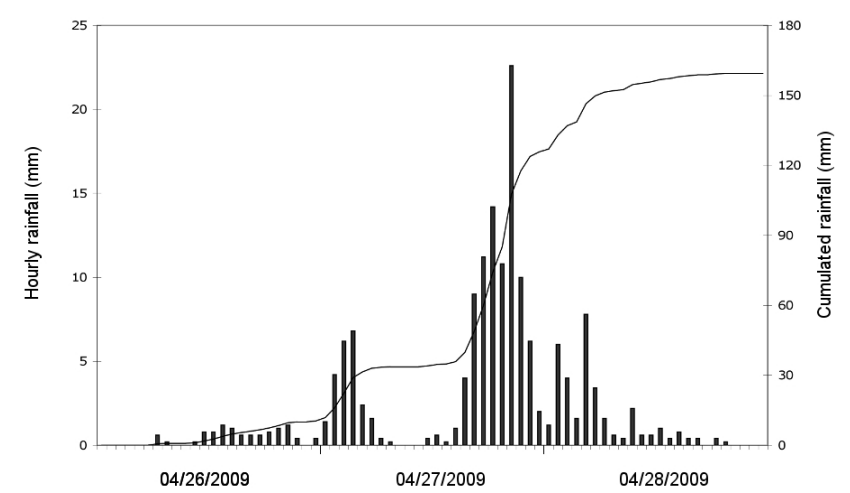

Fig. 2. Hourly and cumulative rainfalls measured over the period from 26 to 28 April 2009 (Cigognola rain gauge).

\section{Materials and methods}

\subsection{The models}

\subsubsection{SINMAP model}

SINMAP outputs the stability index (SI) (Tarboton, 1997; Pack et al., 1999). The stability index is defined as the probability that a location is stable, assuming uniform distributions of the parameters over the uncertainty ranges. The SI ranges between 0 (most unstable) and 1 (stable). At the location at which the most conservative set of parameters (i.e., the set with the most unfavorable combination of parameters for stability) in the model results in stability, the stability index is defined as the factor of safety.

The factor of safety (FS) calculation in SINMAP is based on the infinite slope form of the Mohr-Coulomb failure law, as expressed by the ratio of stabilizing forces (shear strength) to destabilizing forces (shear stress) on a failure plane parallel to the ground surface.

$\mathrm{FS}=\frac{C_{\mathrm{r}}+C_{\mathrm{s}}+\cos ^{2} \theta\left[\rho_{\mathrm{s}} \cdot g\left(D-D_{\mathrm{w}}\right)+\left(\left(\rho_{\mathrm{s}} g-\rho_{\mathrm{w}} g\right) D_{\mathrm{w}}\right] \tan \phi\right.}{D \rho_{\mathrm{s}} \sin \theta \cos \theta}$

where $C_{\mathrm{r}}$ is the root cohesion $\left[\mathrm{N} \mathrm{m}^{-2}\right], C_{\mathrm{s}}$ is the soil cohesion $\left[\mathrm{N} \mathrm{m}^{-2}\right], \theta$ is the slope angle, $\rho_{\mathrm{s}}$ is the wet soil density $\left[\mathrm{kg} \mathrm{m}^{-3}\right], \rho_{\mathrm{w}}$ is the density of water $\left[\mathrm{kg} \mathrm{m}^{-3}\right], g$ is the gravitational acceleration $\left(9.81 \mathrm{~m} \mathrm{~s}^{-2}\right), D$ is the vertical soil depth [m], $D_{\mathrm{w}}$ is the vertical height of the water table within the soil layer [m] and $\phi$ is the internal friction angle of the soil $\left.{ }^{\circ}\right]$.

Following TOPMODEL (a TOPography based hydrological MODEL) (Beven and Kirkby, 1979), SINMAP makes the following assumptions:

1. The shallow lateral subsurface flow follows topographic gradients. This implies that the area contributing to flow at any point is given by the specific catchment area (a) defined by the surface topography. 


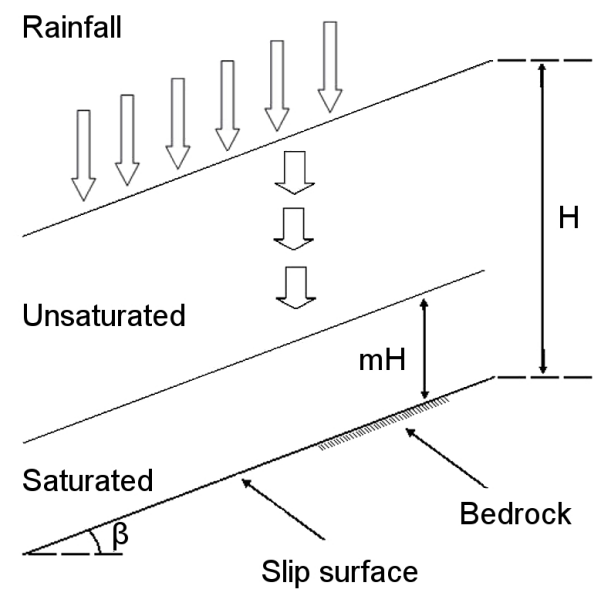

Fig. 3. Diagram of the infinite slope.

2. The lateral discharge $q$ at each point is in equilibrium with a steady-state recharge $R\left[\mathrm{~m} \mathrm{~h}^{-1}\right]$.

3. The capacity for lateral flux at each point is $T \sin \theta$, where $T$ is the soil transmissivity $\left[\mathrm{m}^{2} \mathrm{~h}^{-1}\right]$, i.e., hydraulic conductivity $\left[\mathrm{m} \mathrm{h}^{-1}\right]$ multiplied by soil thickness, h $[\mathrm{m}]$.

Assumptions 1 and 2 together imply that the lateral discharge (depth integrated per unit contour length) is $q=R a$ $\left[\mathrm{m}^{2} \mathrm{~h}^{-1}\right]$. Based on assumption 3, the relative wetness is

$w=\min \left(\frac{R a}{T \sin \theta}, 1\right)$.

The relative wetness, which defines the relative depth of the perched water table within the soil layer, has an upper bound of 1 , with any excess assumed to form overland flow. The ratio $R / T$ in Eq. (2) quantifies the relative wetness in terms of the assumed steady-state recharge relative to the soil's capacity for the lateral drainage of water and combines both climate and hydrogeological factors. The quantity $(T / R) \sin \theta$ [m] may be thought of as the length of hillslope (planar, not convergent) required to develop saturation in the critical wet period being considered.

To define the stability index, the wetness index from Eq. (2) is incorporated into the dimensionless factor of safety which becomes

$\mathrm{FS}=\frac{C+\cos \theta\left[1-\min \left(\frac{R a}{T \sin \theta}, 1\right) r\right] \tan \phi}{\sin \theta}$.

The variables $a$ and $\theta$ are derived from the Digital Elevation Model topography, whereas the values of $C, \tan \phi, r$ and $R / T$ are input by the user. In SINMAP, cohesion is retained in the infinite slope stability model. A dimensionless cohesion factor $C$ is established, combining cohesion due to soil and root properties and soil density and thickness.

SINMAP differentiates between six different classes of the SI. Stable, moderately stable and quasi-stable classes have SIs $>1.5$ and FS $>1.0$, and they represent regions that should not fail with the most conservative parameters in the specified range (destabilizing factors are required for instability, such as local loading and road drainage). For lowerthreshold and upper-threshold classes, the calculated FS is $<1.0$, yet the probability of failure is less than and greater than $50 \%$, respectively. These two classes define a lower and upper limit for ground failure and have SI values of 1.0 to 1.5 and 0 to 1.0 , respectively. In the unconditionally unstable (defended) class, the probability of failure within the specified range of parameters is greatest ( $>90 \%$ probability assumed).

\subsubsection{SHALSTAB model}

The SHALSTAB model predicts the critical rainfall necessary for slope failure throughout a study area (Montgomery and Dietrich, 1994).

The formulation adopted by the model is a combination of hydrological and geomechanical components and is described by the equation:

$i_{c r}=T \sin \theta \frac{b}{A}\left[\frac{\rho_{\mathrm{s}}}{\rho_{\mathrm{w}}}\left(1-\left(1-\frac{C}{\sin \theta \cos \theta}\right) \frac{\tan \theta}{\tan \phi}\right)\right]$

where

$T=k z \cos \theta\left(m^{2} h^{-1}\right)$,

where $T$ is the soil transmissivity, $k$ is the saturated hydraulic conductivity, $z$ is the vertical depth of the soil (depth to bedrock), $\theta$ is the slope angle, $A$ is the drained area, $b$ is the cell width, $\rho_{\mathrm{s}}$ and $\rho_{\mathrm{w}}$ are the soil and water densities, respectively, $C$ is the soil cohesion, and $\phi$ is the internal friction angle.

The predictive index of this model (stability index) is expressed in mm day ${ }^{-1}$ of critical rain and is variable on a scale of values, where lower values indicate a greater propensity for instability and higher values indicate a greater propensity for stability. This scale also encompasses areas identified as unconditionally stable (identified in Figs. $6 b-7 b$ by daily rain amounts greater than $1000 \mathrm{~mm}$ ) and unconditionally unstable based on the value of estimated rain (if $\tan \theta$ equals or exceeds $\tan \phi$, slope instability will occur even under dry conditions).

Important assumptions underlying the SINMAP and SHALSTAB theories include the subsurface hydrologic boundaries being parallel to the surface, uniform soil thickness and hydraulic conductivity, translational slides, a steady-state shallow subsurface flow and the absence of deep drainage and flow in the substratum.

\subsubsection{TRIGRS model}

The Transient Rainfall Infiltration and Grid-Based Regional Slope-Stability Model (TRIGRS) is a Fortran program designed for modeling the timing and distribution of shallow, 
rainfall-induced landslides (Baum et al., 2008). Only a short description is reported here, as many authors have described in detail and used this model in the past decade (Baum et al., 2008; Salciarini et al., 2008; Kim et al., 2010). The model is based on the method outlined by Iverson (2000) with the implementation of complex storm histories, an impermeable basal boundary at a finite depth, and a simple runoff routing scheme. The program computes transient pore-pressure changes and changes in the factor of safety due to rainfall infiltration. It models rainfall infiltration resulting from storms that have durations ranging from hours to a few days using analytical solutions for partial differential equations that represent one-dimensional, vertical flow in isotropic, homogeneous materials for either saturated or unsaturated conditions. The use of step-function series allows the program to represent variable rainfall input, and a simple runoff routing model allows for the diversion of excess water from impervious areas to more permeable downslope areas. The TRIGRS program uses a simple infinite-slope model to compute the factor of safety on a cell-by-cell basis. The factor of safety, FS, is calculated for transient pressure heads at multiple depths $Z$ as follows

$\mathrm{FS}=\frac{\tan \phi^{\prime}}{\tan \beta}+\frac{c^{\prime}-\psi(Z, t) \gamma_{\mathrm{w}} \tan \phi}{\gamma_{\mathrm{s}} Z \sin \beta \cos \beta}$,

where $c^{\prime}$ is the effective soil cohesion, $\phi^{\prime}$ is the soil shear strength angle, $\psi$ is the ground-water pressure head as a function of depth $Z$ and time $t, \beta$ is the slope angle, and $\gamma_{\mathrm{w}}$ and $\gamma_{\mathrm{s}}$ are the unit weights of water and soil, respectively.

The depth $Z$ where FS first drops below 1 is the depth of landslide initiation. This initiation depth depends on soil properties and the time and depth variation of the pressure head, which, in turn, depend on rainfall history. An approximate formula for the effective stress in unsaturated materials aids the computation of the factor of safety in unsaturated soils. Horizontal heterogeneity is accounted for by allowing material properties, rainfall, and other input values to vary from cell to cell.

\subsubsection{The SLIP model}

A detailed derivation of the SLIP model is presented elsewhere (Montrasio, 2000; Montrasio and Valentino, 2008; Montrasio et al., 2011, 2012). In this paper, the necessary relations required for completeness are provided.

To determine the stability condition for shallow landslides, with a maximum depth of approximately 1.5 to $2 \mathrm{~m}$, the infinite slope model can be applied. Moreover, field information from the study sites revealed that the shallow unstable layer was rather thin with respect to the superficial extent of the scars. The model used to describe the triggering mechanism assumes that the potential failure surface is located, with respect to the ground level, at a depth $H$, i.e., where the base layer is less permeable than the upper layer (Fig. 3).
The model assumes that the main hydro-geotechnical process that leads to failure is the saturation of parts of the soil, which can be either immediately above the assumed failure surface or at a higher position.

The slope is initially stable due to the partial saturation of the soil, which contributes to its shear strength. Rainwater flows easily through the macro-pores and reaches the deeper parts of the many natural micro-channels. The hypothesis is that water starts to flow in different directions through the micro-pores of the soil matrix in the zones surrounding the macro-pores. The process continues as rainfall persists, and increasingly larger portions of soil become saturated. The sliding process begins when a relatively wide continuous stratum of saturated soil $(\mathrm{mH})$ has formed.

The stability of a slope is evaluated based on the definition of the safety factor (FS), which is calculated using the limit equilibrium method as the ratio between stabilizing and destabilizing forces. Stabilizing forces are evaluated on the basis of the Mohr-Coulomb strength criterion. The partial saturation contribution to the soil shear strength, in terms of the apparent soil cohesion, is also included. This contribution allows even those slopes characterized by non-cohesive soils to be considered stable in unsaturated conditions, but with a slope angle steeper than the friction angle. The safety factor can be defined as follows

$\mathrm{FS}=\frac{\cot \beta \tan \phi^{\prime}\left[\Gamma+m\left(n_{\mathrm{w}}-1\right)\right]+C^{\prime} \Omega}{\Gamma+m n_{\mathrm{w}}}$

where

$\Gamma=G_{\mathrm{s}}(1-n)+n S_{\mathrm{r}}$

$n_{\mathrm{w}}=n\left(1-S_{\mathrm{r}}\right)$

$\Omega=\frac{2}{\sin 2 \beta H \gamma_{\mathrm{w}}}$

$C^{\prime}=\left[c^{\prime}+c_{\psi}\right] \Delta \mathrm{s}=\left[c^{\prime}+A S_{\mathrm{r}}\left(1-S_{\mathrm{r}}\right)^{\lambda}(1-m)^{\alpha}\right] \Delta \mathrm{s}$

$m=\frac{\xi}{n H\left(1-S_{\mathrm{r}}\right)} \sum_{i=1}^{\omega} h_{i} \exp \left[-K_{T}\left(t-t_{i}\right)\right]$

The symbols in Eqs. (7) through (12) have the following meanings: $\beta$ is the slope angle; $\phi$ ' is the shear strength angle of the soil; $\gamma_{\mathrm{w}}$ is the unit weight of water; $H$ is the thickness of the potentially unstable layer; $\Delta \mathrm{s}$ is the unit length of the soil slice; $m$ represents the saturated fraction of the soil layer with respect to its thickness $H ; n$ is the porosity of the soil; $G_{\mathrm{S}}$ is the specific weight of the soil; $S_{\mathrm{r}}$ is the degree of saturation of the soil; c' is the effective soil cohesion; $c \psi$ is the apparent cohesion given by the partial saturation of the soil; $A, \lambda$ and $\alpha$ are numerical calibration parameters; $\xi$ is a runoff coefficient; $K_{T}$ is the discharge capacity of the slope; $t$ is the moment of time being considered; and $t_{i}$ is the 
time (day) to which the rainfall depth $h_{i}$ corresponds. The direct correlation between the safety factor FS and the rainfall depth is achieved by considering the factor $m$ as a function, at each time step, of previous rainfalls and of the parameter $K_{T}$, which is linked to the drainage coefficient of the soil. A detailed description of the model is provided by Montrasio and Valentino (2008) and Montrasio et al. (2011).

\subsection{The input parameters}

\subsubsection{Landslide inventory}

Color aerial photographs taken immediately after 27 and 28 April 2009, in the northeastern part of Oltrepo Pavese, with an image resolution of $15 \mathrm{~cm}$ (photo scale of 1:12000), were studied to map the existing landslides.

Field investigations (carried out two days after the rainstorm) required a detailed study of the failure site geomorphology and the characteristics of the landslides. Detailed field surveys were also conducted to detect slope failures and study landslide elements (e.g., scarp and body). The description of landslides includes the type of movement according to the classification of landslides described by Campus et al. (1998) and Cruden and Varnes (1996). The presence or absence of groundwater seepage and the location of landslides, with respect to land use, were also recorded.

Three sets of aerial photographs, taken in 1980, 2003 and 2009, were used to map the evolution of land cover and to study its relationship with shallow landslide occurrence in the last $30 \mathrm{yr}$.

Aerial photo interpretation, coupled with field surveys, revealed that the rainfall event of April 2009 triggered 491 landslides in area 1 and 256 in area 2 (Fig. 1). Most of the landslides were shallow (thicknesses were generally between 0.5 and $2 \mathrm{~m}$ ), with the failure surface located along the border between the colluvial cover and the weathered bedrock and, in some cases, involving portions of the bedrock. According to the classification of Cruden and Varnes (1996) and that proposed by Campus et al. (1998) for rainfalltriggered landslides, five types of landslides can be identified in the study site: (a) incipient translational slides: fractures are present in the terrain but the displaced mass has limited movements with little internal deformation; (b) translational soil slides; (c) rotational slide-translational slides: generally develop in the presence of a road cut; (d) complex landslides: the landslide is initiated as an ensemble of shallow rotationaltranslational failures and then evolves into earth flow due to hillslope runoff during continuous rainfall, extending for a considerable distance down the slope (some slides of this type have a length of up to $250 \mathrm{~m}$ ); and (e) disintegrating soil slips: due to the increase in water content, the disrupted mass may flow, making it difficult to identify the accumulation zone.

Most parts of the landslides in area 1 are of types $b$ and d, which satisfies the assumption of physically based methods of a failure surface parallel to the slope surface. In area 2, the landslide typologies and sizes are quite different; shallow landslides are represented by type $\mathrm{c}$, which develop in the presence of road cuts.

Common characteristics of shallow landslides are the coalescence of scars and/or accumulations and limited dimensions (surface area of less than $1000 \mathrm{~m}^{2}$ ).

The comparison of aerial photographs of different periods (1954, 1980, 1994, 2000, 2003, and 2007) did not reveal similar phenomena in the past, which may be due to the extinction rate of scars resulting from human activities. Only a few deep landslides were identified.

Landslides appear on NW- and NE-oriented slopes and were observed in a slope range from 16 to $37^{\circ}$. The highest landslide frequency corresponds to slope angles between 25 and $30^{\circ}$.

Most of the landslides tended to be concentrated in areas where the slope angle changed from a gentle slope to a steep slope or vice versa.

Changes in land cover have played a major role in landslide occurrence and distribution, especially in the study area 1. Over the study period (1980-2009), significant changes occurred in land cover, particularly as a result of changing agricultural practices, which caused a significant modification of runoff conditions. Until the 1980s, traditional vineyard plantations used a tillage pattern oriented across the maximum slope gradient. Agricultural work was undertaken in the traditional manner with weeding and digging; thus, runoff and sediment transport were partially controlled. After the 1980s, traditional vineyards disappeared and were replaced by modern vineyards with rows parallel to the maximum slope gradient (upslope and downslope) to optimize the vine density and the mechanical work. In area 1 , from 1980 to 2009, woodland areas increased from 8 to $45 \%$ as a consequence of the recolonization of abandoned vineyards. The roots generally extend into the first meters of the soil profile and are involved in the landslides. In the abandoned vineyards, the old tillage pattern oriented across the maximum slope gradient allows for the concentration of water. This explains the occurrence of a great number of landslides in woodland areas.

For validation of the models through the use of ROC curves, a detailed database of landslide source areas was manually built, identifying the landslides with simpler morphology at the point in the scar with maximum curvature; for the more complex shapes or in the case of large landslides, more than one point was taken into account.

Two different data sets of shallow landslides were used as input data for the physically based models: the first data set considers all typologies of landslides, and the second excludes the slides that occur on the slopes adjacent to the roads, which are considered to be due to anthropologically induced instabilities (Fig. 9). 


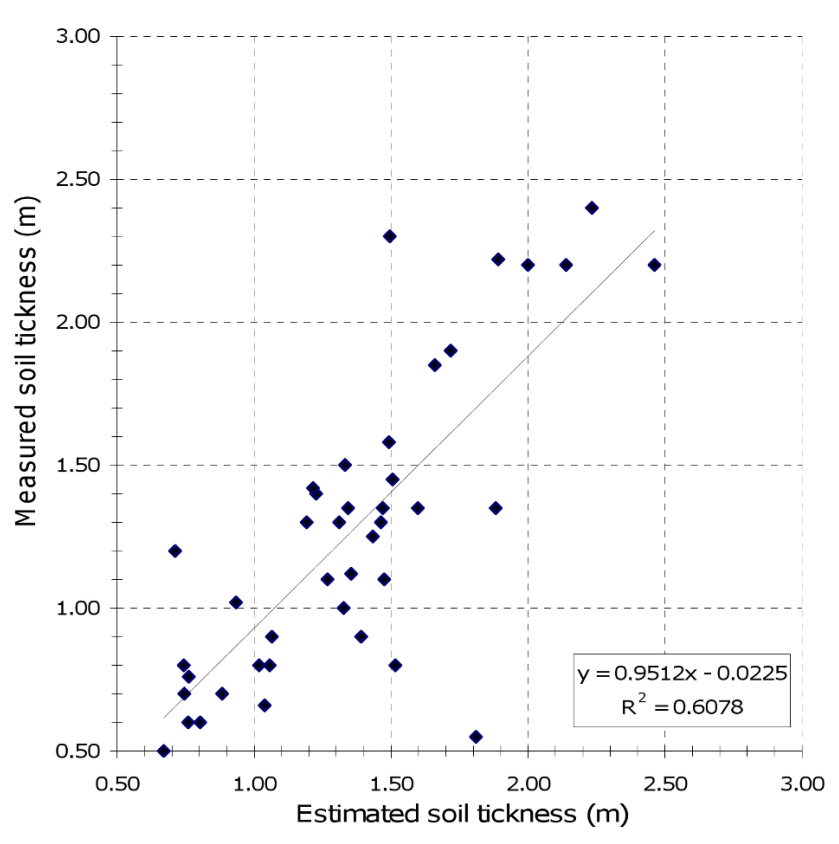

Fig. 4. Measured vs. estimated soil thickness.

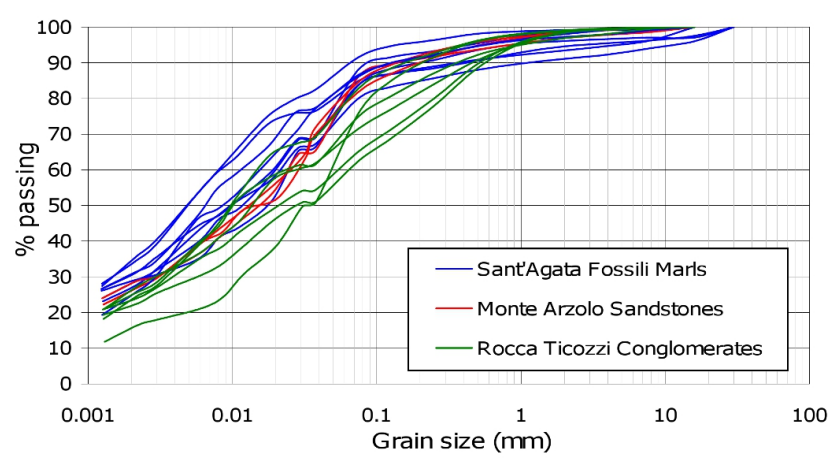

Fig. 5. Grain size distribution curve of soils.

\subsubsection{Soil parameters}

The geology of the study area is based on the research of Vercesi and Scagni (1984) (Fig. 1). Several field surveys were carried out to characterize the lithostratigraphic formations identified by Vercesi and Scagni (1984) and the colluvial deposits derived by weathering of the bedrock.

Soil thickness was derived from field data collected after the April 2009 event. We used a geomorphologically indexed model based on the local slope angle, the elevation (h) and the topographic position (TP) (Fig. 4):

$$
\begin{aligned}
& \text { DTB }=w \mathrm{wm}\left[h_{\max }-\frac{z_{i}-z_{\min }}{z_{\max }-z_{\min }}-\left(h_{\max }-h_{\min }\right)\right] \\
& +\left[h_{\max }\left(1-\frac{\tan \theta i-\tan \theta_{\min }}{\tan \theta_{\max }-\tan \theta_{\min }}\left(1-\frac{h_{\min }}{h_{\max }}\right)\right)\right], \\
& +\left[h_{\max }-\frac{\mathrm{TP}_{n i}-\mathrm{TP}_{n} \min }{\mathrm{TP}_{n} \max -\mathrm{TP}_{n} \min }-\left(h_{\max }-h_{\min }\right)\right]
\end{aligned}
$$

where wm is the weighted mean; $h_{\max }$ and $h_{\min }$ are the maximum and minimum depths to bedrock, respectively; $Z_{i}$ is the elevation at point $i ; Z_{\max }$ and $Z_{\min }$ are the maximum and minimum elevations found in the area, respectively; $\theta$ is the slope angle; and $\mathrm{TP}_{i}$ and $\mathrm{TP}_{n}$ represent the topographic position and normalized topographic position, respectively.

$$
\begin{aligned}
\mathrm{TP}_{i} & =Z_{i}-\operatorname{Mean}\left(Z_{i}\right) \\
\mathrm{TP}_{n} & =\frac{1}{1+\exp ^{-\mathrm{TP} i}}
\end{aligned}
$$

For some landslides, a detailed stratigraphic profile was constructed, and undisturbed and remolded soil samples corresponding to shallow landslide scars were collected for laboratory investigations.

The geotechnical characterization of the slope colluvial deposits in the study area was based on standard soil analysis conducted according to the ASTM (American Society for Testing and Materials) standards. The performed tests included (i) assessment of the physical parameters of materials (grain size distribution, bulk and dry densities, and Atterberg limits) and (ii) direct shear tests, performed in the 100 to $300 \mathrm{kPa}$ stress range, which allowed for the determination of shear strength parameters in terms of effective stresses.

The hydraulic conductivity of the saturated soils was determined through field tests in the representative areas (variable load well tests) of colluvial soils on S. Agata Fossili Marls and from pedological maps of the other soils.

Field surveys coupled with laboratory test results allowed for the construction of the geological model of the study area.

The soils involved in the shallow landslides are represented by the colluvial deposits derived by the weathering of the bedrock belonging to the lithostratigraphical formations of S. Agata Fossili Marls, M. Arzolo Sandstones, and Rocca Ticozzi Conglomerates. Soil parameters, which were assigned to each class after performing an averaging procedure on approximately 80 samples, are reported in Table 1 .

On the basis of grain-size distribution, the following classification was carried out: the colluvial soils derived from the weathering of the S. Agata Fossili Marls were classified as clayey silt (the amount of clay is less than $35 \%$ ), whereas the colluvial soils derived from the weathering of M. Arzolo Sandstones and Rocca Ticozzi Conglomerates were classified as clayey sandy silt (the amount of sand is generally more than 15\%) (Fig. 5). According to the USCS classification, the majority of the analyzed samples are non-plastic or slightly plastic soils (CL). Coarse fragments consisting of marls or sandstone derived from the underlying bedrock are also present in the colluvial deposits.

The geotechnical soil profiles do not show significant geotechnical dependence on depth. Nevertheless, below the cover forming the interface, between the soil layers and the bedrock, there is a thin layer of silty clay derived from the direct weathering of the bedrock. This finding satisfies another assumption of the physically based methods, namely 


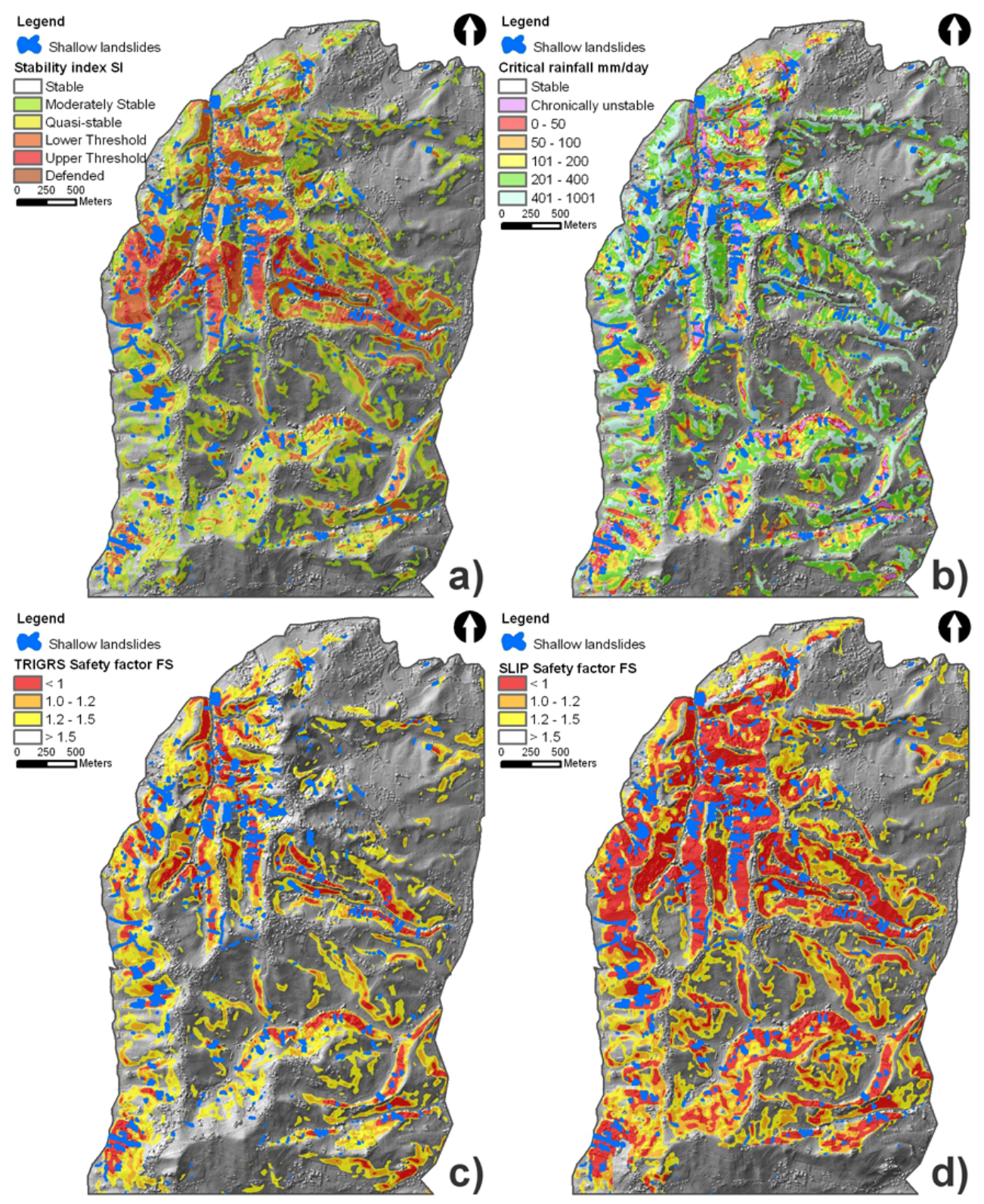

Fig. 6. Landslide susceptibility map of area 1: (a) Stability index map obtained by SINMAP; (b) Critical intensity of rainfall (mm day ${ }^{-1}$ ) computed by SHALSTAB; (c) Safety factor map obtained using TRIGRS; and (d) Safety factor map obtained using SLIP.

the absence of deep drainage and flow in the substratum. In a large number of cases, these thin layers constitute the sliding surface of the landslide.

The colluvial deposits have medium-high permeability; the bedrock of M. Arzolo Sandstones and Rocca Ticozzi Conglomerates is also highly permeable. Extensive perched water table development is common on these colluvial soil slopes, especially during the rainy season.

\subsection{Application of the models}

A digital elevation model (DEM) with a grid size of $10 \times 10 \mathrm{~m}$ provides the topographic basis.

For the analysis with the different methods, the study area was divided into four regions characterized by homogeneous in situ conditions and soil properties and corresponding to the lithostratigraphic units.

The hourly rainfall intensities recorded by the Cigognola rain gauge during the April 2009 event were assumed to be boundary conditions at the slope surface. 


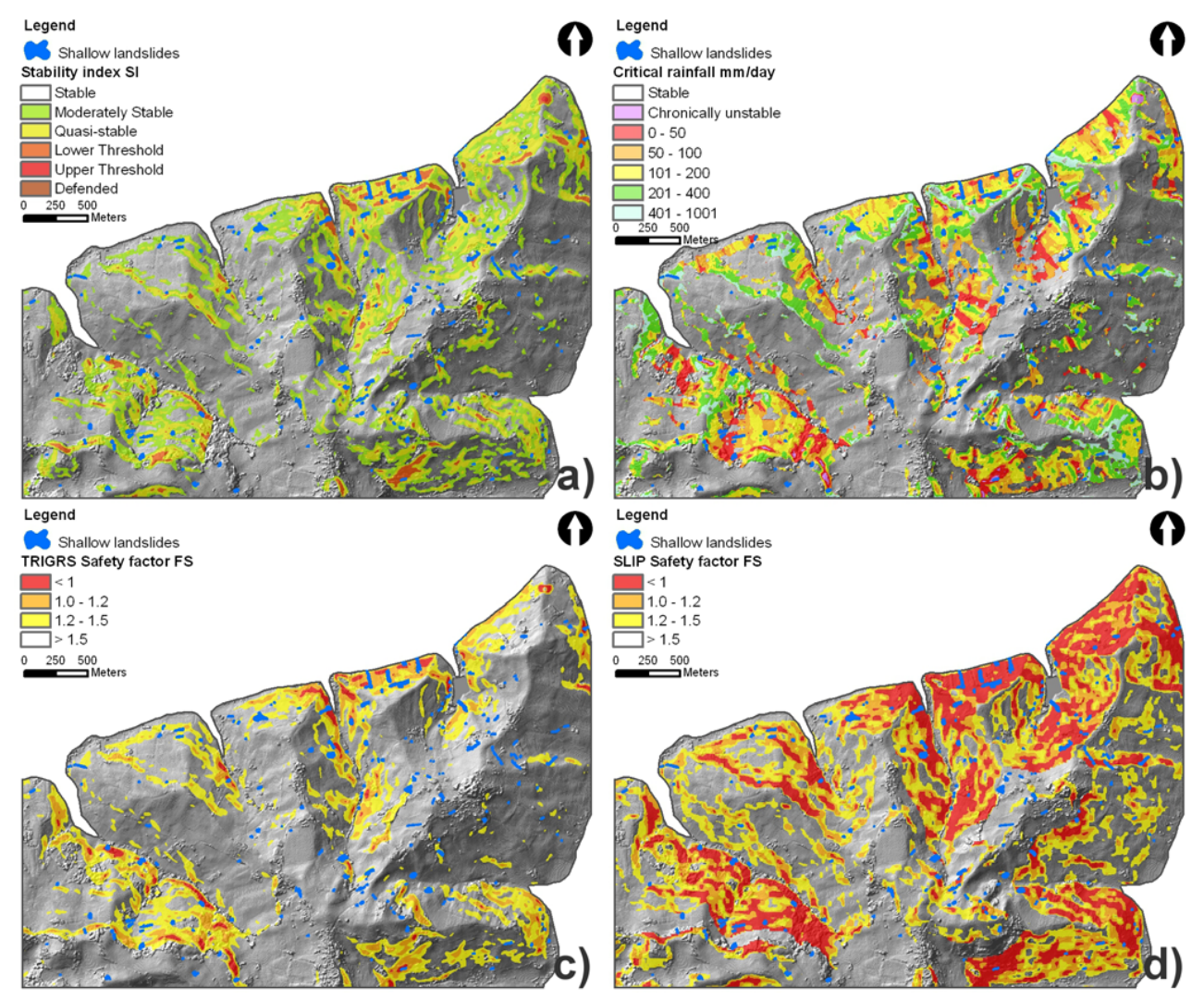

Fig. 7. Landslide susceptibility map of area 2: (a) Stability index map obtained by SINMAP; (b) Critical intensity of rainfall (mm day ${ }^{-1}$ ) computed by SHALSTAB; (c) Safety factor map obtained using TRIGRS; and (d) Safety factor map obtained using SLIP.

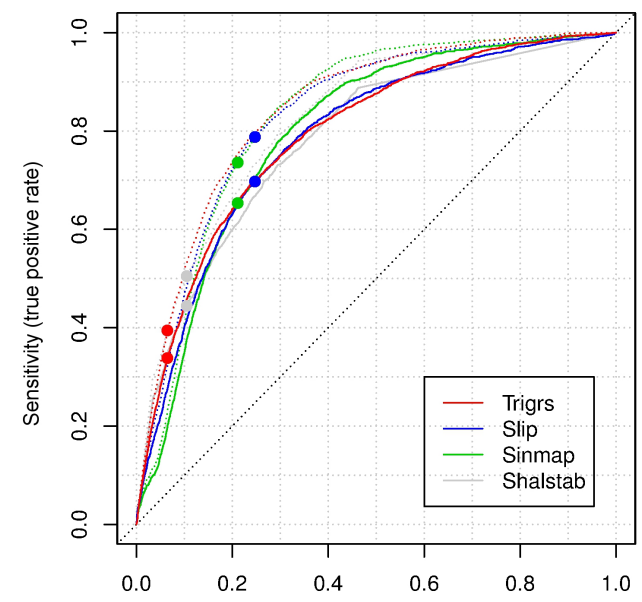

a)

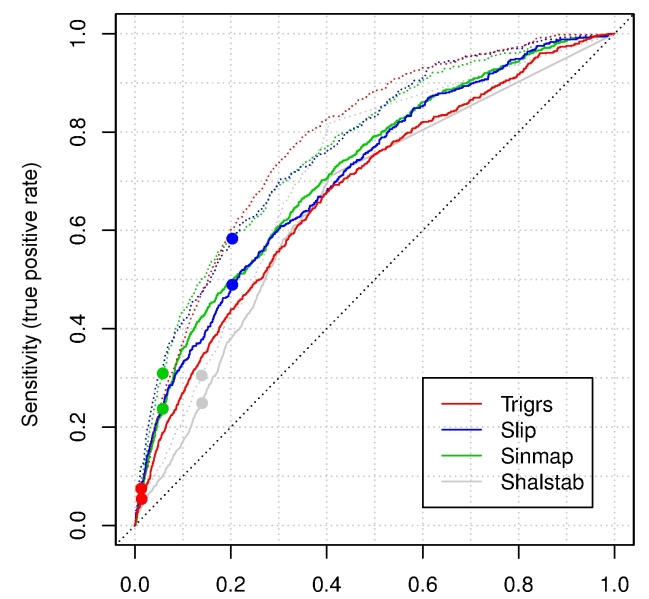

b)

1 - Specificity (false positive rate)

Fig. 8. ROC curves derived for: (a) area 1 and (b) area 2. Dashed lines represent the results of analyses that did not consider landslides of type (c), whereas colored dots represent the positions along curves where FS $=1$ for TRIGRS and SLIP, SI $=1$ for SINMAP and critical rainfall is equal to $100 \mathrm{~mm}_{\text {day }}{ }^{-1}$ for SHALSTAB.

For SINMAP, the $R / T$ ratio combines both climate and hydrogeological factors (Table 2). The transmissivity $T$ represents the water flow within the soil and was derived from the hydraulic conductivity (minimal and maximal). The pa- rameter $R$ (steady-state recharge rate) is influenced by factors such as rainfall intensity and duration. The recharge was assumed to be the effective precipitation, calculated as the rainfall minus evapotranspiration and bedrock infiltration. For 
Table 1. Geotechnical characteristics of the colluvial soils involved in shallow landslides.

\begin{tabular}{|c|c|c|c|c|c|c|c|c|c|}
\hline $\begin{array}{l}\text { Lithostratigraphic } \\
\text { formations }\end{array}$ & $\begin{array}{l}\text { clay } \\
(\%)\end{array}$ & $\begin{array}{l}\text { silt } \\
(\%)\end{array}$ & $\begin{array}{l}\text { sand } \\
(\%)\end{array}$ & $\begin{array}{l}\mathrm{w}_{l} \\
(\%)\end{array}$ & $\begin{array}{l}\text { PI } \\
-\end{array}$ & $\begin{array}{l}\gamma_{d} \\
\left(\mathrm{kN} \mathrm{m}^{-3}\right)\end{array}$ & $\begin{array}{l}\mathrm{n} \\
-\end{array}$ & $\begin{array}{l}\mathrm{c}^{\prime} \\
(\mathrm{kPa})\end{array}$ & $\begin{array}{l}\phi \\
\left(^{\circ}\right)\end{array}$ \\
\hline $\begin{array}{l}\text { Monte Arzolo } \\
\text { Sandstone }\end{array}$ & $23-37$ & $49-71$ & $4-22$ & $40-48$ & $15-28$ & $15-16.3$ & $0.40-0.44$ & $0-7$ & $23-30$ \\
\hline $\begin{array}{l}\text { Rocca Ticozzi } \\
\text { Conglomerates }\end{array}$ & $12-27$ & $20-59$ & $16-50$ & $30-43$ & $8-18$ & $15.2-16.3$ & $0.44-0.47$ & 2 & 32 \\
\hline $\begin{array}{l}\text { S. Agata } \\
\text { Fossili Marls }\end{array}$ & $24-35$ & $44-61$ & $8-14$ & $39-48$ & $20-29$ & $15.3-15.8$ & $0.39-0.42$ & $7-10$ & $24-27$ \\
\hline $\begin{array}{l}\text { Gessoso-Solfifera } \\
\text { Formation }\end{array}$ & $33-39$ & $47-52$ & $4-16$ & $45-47$ & $24-27$ & - & - & $4-7$ & $25-27$ \\
\hline
\end{tabular}

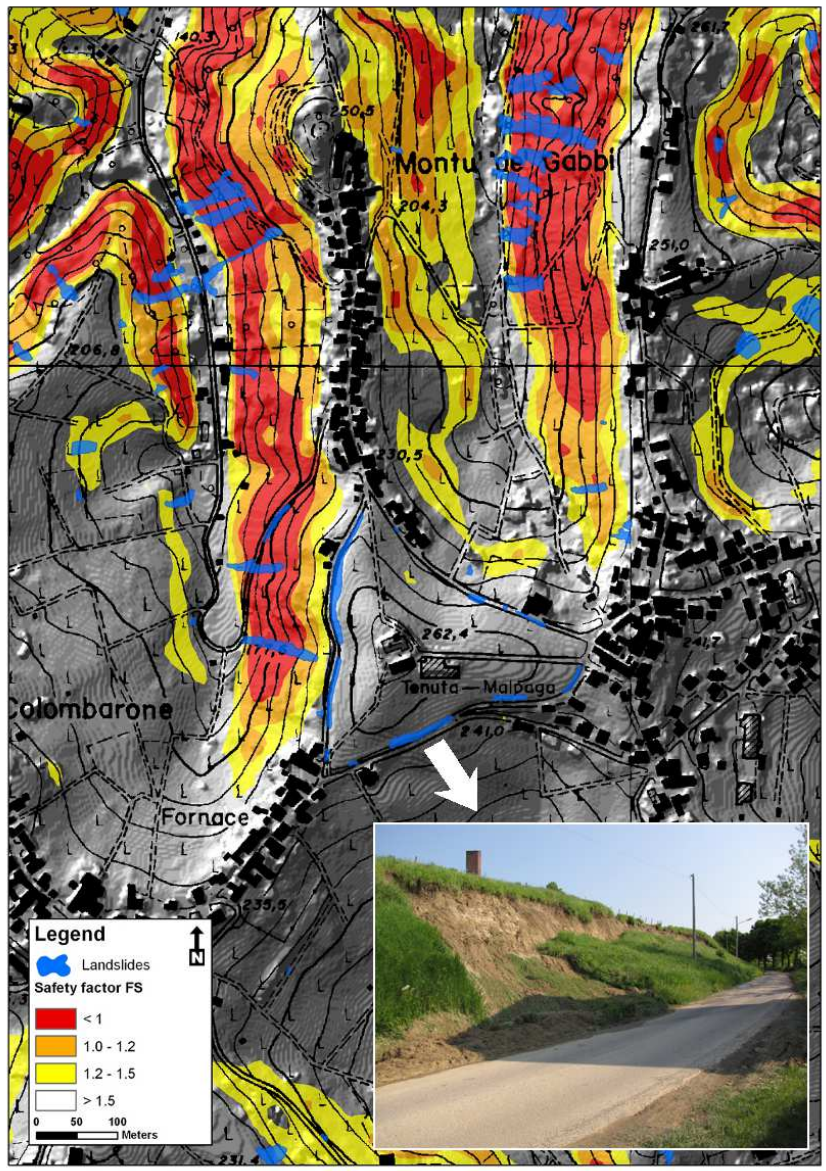

Fig. 9. Landslides of type c near "Tenuta Malpaga" in the municipality of Canneto Pavese.

each region, the potential evapotranspiration was calculated from the rainfall and temperature according to the Thornthwaite and Mather method (1957). The land use map allowed for the determination of the water holding capacity necessary for the evapotranspiration calculation. The infiltration amount depends on the slope angle, and we assumed that only $1 / 4$ of the water infiltrates into the substratum.

For the TRIGRS initial conditions, a water table depth corresponding to $0.75 \mathrm{~m}$ below the ground level was assumed, as effectively observed during the April 2009 event.

The SLIP model was applied to the study area on the basis of territory information. In particular, to reach the goal of the present work, the territory was divided into a $10 \times 10 \mathrm{~m}$ grid, where each cell was independently modeled based on its own soil features. The slope angle $(\beta)$ corresponding to each cell was derived from a digital terrain model (DTM) with the same resolution of $10 \mathrm{~m}$, and geotechnical data were assigned to each cell based on lithological maps previously produced for the area (Fig. 1). In particular, four different classes of shallow soil were identified in the study area, each corresponding to a different geological formation. The geotechnical parameters of the potentially unstable soil covers were assigned as a function of the soil type and on the basis of previously described laboratory test results. Soil input parameters assigned to each class are reported in Table 4.

All input data were acquired by from a GIS database in "raster" form. For each parameter used in the model, a map was generated at the same spatial resolution $(10 \times 10 \mathrm{~m})$. In particular, the values of the shear strength angle $(\phi ')$, the soil porosity $(n)$ and the specific weight $\left(G_{\mathrm{s}}\right)$ for each type of shallow soil (Table 4) were chosen as the mean values of parameters obtained from laboratory tests (Table 1). Regarding the shallow soil covering the Gessoso-Solfifera Formation, only shear strength laboratory tests have been carried out, and parameters of $n=0.48$ and $G_{\mathrm{s}}=2.7$ were assumed on the basis of the literature (Lancellotta, 2004).

With regard to the effective cohesion (c'), direct shear tests revealed values in the range of 0 to $10 \mathrm{kPa}$ (Table 1), representing all types of the investigated soils. Due to the high importance of this strength parameter in the stability analysis of shallow soils, and considering that the effective cohesion derived from direct shear tests could be overestimated for shallow soils (Nova, 2010; Lancellotta, 2004), a precautionary 

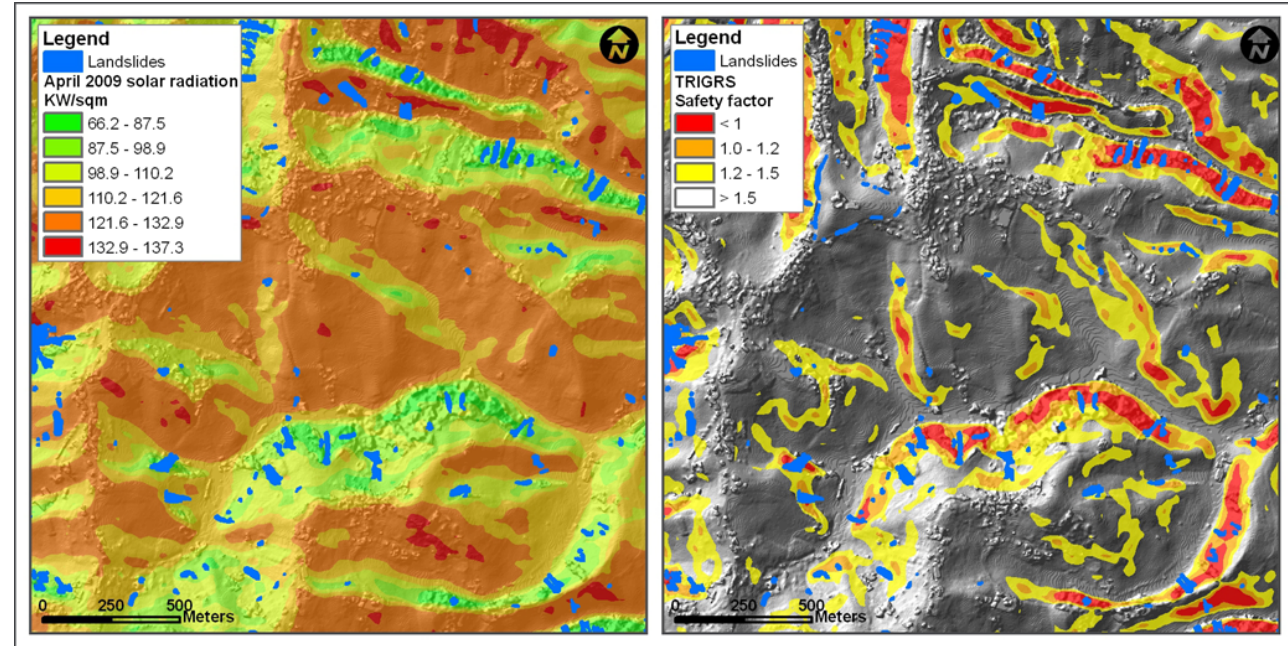

Fig. 10. Cumulative potential global solar radiation in April 2009 (values are expressed in kilowatts per square meter) and safety factor map computed by TRIGRS.

Table 2. Initial values of the input parameters for SINMAP. $C_{\mathrm{r}}$ is the root cohesion $\left[\mathrm{N} \mathrm{m}^{-2}\right], C^{\prime}$ is the soil cohesion $\left[\mathrm{N} \mathrm{m}{ }^{-2}\right], \theta$ is the slope angle, $\rho_{\mathrm{s}}$ is the wet soil density $\left[\mathrm{kg} \mathrm{m}^{-3}\right], \rho_{\mathrm{W}}$ is the density of water $\left[\mathrm{kg} \mathrm{m}^{-3}\right], g$ is the gravitational acceleration $\left(9.81 \mathrm{~m} \mathrm{~s}^{-2}\right), D$ is the vertical soil depth $[\mathrm{m}], \phi$ is the internal friction angle of the soil, h $[\mathrm{m}]$ is the soil thickness, $T$ is the soil transmissivity $\left[\mathrm{m}^{2} \mathrm{~h}^{-1}\right]$, and $R$ is the steady-state recharge $\left[\mathrm{m} \mathrm{h}^{-1}\right]$.

\begin{tabular}{|c|c|c|c|c|c|c|c|c|c|}
\hline \multirow[t]{2}{*}{ Region } & \multicolumn{2}{|c|}{$\phi\left(^{\circ}\right)$} & \multicolumn{2}{|c|}{$C=\left(C_{\mathrm{r}}+\mathrm{C}^{\prime}\right) /\left(\mathrm{hg} \rho_{\mathrm{s}}\right)$} & \multicolumn{2}{|c|}{$T=\mathrm{k} \mathrm{D}\left(\mathrm{m}^{2} \mathrm{~h}^{-1}\right)$} & \multirow{2}{*}{$\begin{array}{l}\mathrm{R} \\
\left(\mathrm{mh}^{-1}\right)\end{array}$} & \multicolumn{2}{|c|}{$T / R(\mathrm{~m})$} \\
\hline & $\min$ & $\max$ & $\min$ & $\max$ & $\min$ & $\max$ & & $\min$ & $\max$ \\
\hline S. Agata Fossili Marls & 24 & 25.4 & 0.1856 & 0.8909 & 0.0367 & 1.6682 & 0.0434 & 0.8453 & 38.4043 \\
\hline Rocca Ticozzi Conglomerates & 30 & 33.7 & 0.1908 & 0.8712 & 0.0648 & 1.6599 & 0.0434 & 1.4917 & 38.2130 \\
\hline M. Arzolo Sandstones & 23.3 & 29.9 & 0.0662 & 0.3065 & 0.2798 & 1.6207 & 0.0434 & 6.4423 & 37.3092 \\
\hline Gessoso-Solfifera Formation & 22 & 27 & 0.3722 & 0.6435 & 0.0324 & 1.5178 & 0.0434 & 0.77458 & 34.9414 \\
\hline
\end{tabular}

zero value of the effective cohesion for all of the involved soils was considered in the stability analysis.

As previously explained, the parameter $K_{T}$ was determined in relation to the permeability of each soil type based on previous studies (Meisina and Scarabelli, 2007). Table 4 reports the different values of $K_{T}$ chosen for each soil class.

Other model parameters, such as $A$ and $\lambda$, whose significance have been previously described, were considered constant for each soil class (Table 4) because, regardless of the type of subsoil formation, the shallow soil in the considered area is commonly a clayey silt. On the basis of experimental results reported elsewhere (Fredlund et al., 1996; Lu et al., 2007; Montrasio and Valentino, 2008) for silty soils, we assumed the following model parameter values: $\lambda=0.4$ and $A=40$ (Table 4).

The model parameter $\alpha$ was considered equal to 3.4 everywhere on the basis of experimental measurements (Montrasio and Valentino, 2007). The coefficient $\xi$ (Eq. 16), which accounts for both runoff and leakage, is considered a constant calibration coefficient and was assumed to be equal to 0.7 everywhere.
In the analyzed area, the potentially unstable depth $H$ was evaluated on the basis of field measurements, and, for each geological class, an average value was assumed.

Moreover, on the basis of field surveys and taking into account the land use map, the areas occupied by buildings and orchards were disregarded in the slope-stability analysis.

The degree of saturation $\left(S_{\mathrm{r}}\right)$ is influenced by climatic conditions and seasonal weather. Experimental measurements show that in the study areas, for the soil at the depths concerned, $S_{\mathrm{r}}$ generally ranges from a minimum of 0.6 in summer to a maximum of 0.9 in winter (Meisina and Scarabelli, 2007; Montrasio et al., 2010). For this reason, the value of $S_{\mathrm{r}}$ was considered constant and equal to 0.9 for the reference dates and the entire analyzed area.

Rainfall data were added to the input data so that each cell had a corresponding rainfall depth. In particular, rainfall data were obtained from the rain gauges located in the areas of interest. The interpolation method used for the definition of the rainfall pattern was based on the inverse-square distance weighting method, which was applied to each point with respect to the position of the rain gauges. The output of the 
Table 3. Input parameters for the SHALSTAB and TRIGRS models.

\begin{tabular}{lllllllll}
\hline Region & \multicolumn{2}{c}{$\phi\left(^{\circ}\right)$} & \multicolumn{2}{c}{$\mathrm{C}^{\prime}\left[\mathrm{N} \mathrm{m}^{-2}\right]$} & \multicolumn{2}{c}{$\rho \mathrm{s}\left[\mathrm{kN} \mathrm{m}^{-3}\right]$} & \multicolumn{2}{c}{$\left.\mathrm{k} \mathrm{m} \mathrm{s}^{-1}\right]$} \\
& $\min$ & $\max$ & $\min$ & $\max$ & $\min$ & $\max$ & $\min$ & $\max$ \\
\hline S. Agata Fossili Marls & 24 & 25.4 & 2000 & 10000 & 17.946 & 18.701 & $1.7 \times 10^{-5}$ & $1 \times 10^{-4}$ \\
Rocca Ticozzi Conglomerates & 30 & 33.7 & 2000 & 10000 & 17.455 & 19.122 & $3.0 \times 10^{-5}$ & $1 \times 10^{-4}$ \\
M. Arzolo Sandstones & 23.3 & 29.9 & 1400 & 7900 & 17.651 & 19.907 & $6.5 \times 10^{-5}$ & $1 \times 10^{-4}$ \\
Gessoso-Solfifera Formation & 22 & 27 & 3900 & 7500 & 17.455 & 19.417 & $1.5 \times 10^{-5}$ & $1 \times 10^{-4}$ \\
\hline
\end{tabular}

Table 4. Input parameters for the SLIP model.

\begin{tabular}{lccccccccc}
\hline Lithostratigraphic formations & $H(\mathrm{~m})$ & $\phi^{\prime}\left({ }^{\circ}\right)$ & $\mathrm{c}^{\prime}(\mathrm{kPa})$ & $\lambda$ & $A$ & $n$ & $G_{\mathrm{S}}$ & $K_{T}\left(d^{-1}\right)$ & $\alpha$ \\
\hline Monte Arzolo Sandstone & 0.8 & 26 & 0 & 0.4 & 80 & 0.42 & 2.75 & 0.604 & 3.4 \\
Rocca Ticozzi Conglomerates & 1.1 & 32 & 0 & 0.4 & 80 & 0.45 & 2.90 & 0.777 & 3.4 \\
S. Agata Fossili Marls & 0.8 & 25 & 0 & 0.4 & 80 & 0.40 & 2.64 & 0.432 & 3.4 \\
Gessoso-Solfifera Formation & 1.2 & 26 & 0 & 0.4 & 80 & 0.48 & 2.70 & 0.864 & 3.4 \\
\hline
\end{tabular}

model, in terms of the safety factor map, was produced on the basis of rainfall conditions for the previous 30 days with respect to the selected date.

\section{Model comparison and discussion}

Different landslide susceptibility maps were created from the four models using the two landslide databases in the two areas. The applied approaches assumed diverse hydrological models, as was previously explained. SINMAP, SLIP and TRIGRS output the stability index and the safety factor, whereas SHALSTAB outputs the critical rainfall (Figs. 6, 7).

The outputs obtained from the different models for the event of 27 April and 28 April 2009, were further analyzed to quantify the spatial discrepancy between the landslides triggered by the April 2009 rainfall event and the model results. The reliability of each model was evaluated through ROC analysis (Begueria, 2006b). When classifying a grid from the unstable map, four outcomes are possible. If a computed unstable cell is inside the observed landslide area, it is counted as true positive $(t p)$; if it is outside the observed landslide area, it is counted as false positive $(f p)$. If a computed stable cell corresponds to an observed landslide cell, it is counted as false negative $(f n)$; otherwise, it is classified as true negative (tn).

To perform the ROC analysis, two quantities were calculated: sensitivity (true positive rate), defined as the ratio between $t p$ and the sum of $t p$ and $f n$; and specificity (false positive rate), defined as the ratio between $t n$ and the sum of th and $f p$. Different points of the ROC curve were obtained by assuming, at each step, a different threshold value of the safety factor.

In the ROC plot, the sensitivity of the model is plotted against the 1-specificity. These values indicate the ability of the model to correctly discriminate between positive and neg- ative observations in the validation sample. A high sensitivity indicates a high number of correct predictions, whereas a high specificity indicates a low number of false positives. The area under the ROC curve can serve as a global accuracy statistic for the model. This statistic ranges from 0.5 (random prediction, represented by a diagonal straight line) to 1 (perfect prediction) and can be used for model comparisons (Cervi et al., 2010).

Figures $8 \mathrm{a}$ and $\mathrm{b}$ show the ROC plots derived from the models for areas 1 and 2, respectively.

The global accuracy (Table 5) represented by the area under the ROC curve (AUC) of SINMAP was equal to 0.79. Approximately $18.7 \%$ of study area 1 is classified with a SI below one (upper threshold and lower threshold classes), which corresponds to conditions that are highly unstable and thus critical, so the model is rather conservative. The same performance was measured for TRIGRS (AUC $=0.79$, area with $\mathrm{FS}<1=6.9 \%$ ). The global accuracy was 0.78 for the stability analyses in SLIP (area with FS $<1=22.5 \%$ ) and was 0.78 for SHALSTAB (area with critical rainfall lower than $100 \mathrm{~mm} \mathrm{day}^{-1}=11 \%$ ); the incidence of shallow landslides is high for areas mapped as "chronic" and for areas with critical rainfall lower than $200 \mathrm{~mm} \mathrm{day}^{-1}(150 \mathrm{~mm}$ of rain in $48 \mathrm{~h}$ was recorded in the April 2009 event). This demonstrates that SHALSTAB is successful in identifying the most unstable areas of the landscape and also allows spatially distributed rainfall thresholds to be derived.

The research demonstrates that the four physically based models, although they use different hydrological models, have quite similar degrees of success as far as the prediction of shallow landslide source areas in study site 1 . Generally, the model performance increases when considering the database without the shallow landslides occurring in correspondence with road slopes, namely type c (Table 5). 
Table 5. Global accuracy of the models (area under the ROC curve).

\begin{tabular}{lllll}
\hline \multirow{2}{*}{ Model } & \multicolumn{2}{c}{ AUC Area 1 } & \multicolumn{2}{c}{ AUC Area 2 } \\
\cline { 2 - 5 } & All landslides & Without c & All landslides & Without c \\
\hline SINMAP & 0.7965 & 0.8326 & 0.7184 & 0.766 \\
SHALSTAB & 0.7846 & 0.8256 & 0.6573 & 0.7118 \\
TRIGRS & 0.7943 & 0.8453 & 0.6793 & 0.7810 \\
SLIP & 0.7852 & 0.8312 & 0.6824 & 0.6620 \\
\hline
\end{tabular}

Most of the models fail in the identification of landslides with a source area of type c (even when the assumption of a movement parallel to the slope is verified); these types of landslides are often located along road embankments. Although characterized by steep slopes, they are not easily identifiable in the slope map due to its low resolution. Their dimensions are too small compared with the minimum kernel dimension used in the slope algorithm. Figure 9 shows eleven landslides localized along the road that surrounds the Cascina Malpaga that were not recognized by any of the models used in this study.

Ignoring this type of landslide in the ROC analysis, in area 1, TRIGRS, SLIP and SINMAP correctly identified approximately $80 \%$ of the source areas with a $25 \%$ falsepositive rate. SHALSTAB reached an accuracy of $80 \%$ with a $30 \%$ false-positive rate. If we consider the initial section of the curve as clearly visible, there is a greater propensity for a conservative prediction by SINMAP; specifically, the true positive rate values achieved by the other models coincide with a $5 \%$ higher false-positive rate by SINMAP.

In area 2, the global accuracies of the models were generally lowest, even when excluding type c landslides; specifically, TRIGRS had the best performance, whereas SLIP overestimated the susceptibility. These results can be justified both by the high number of landslides of type $c$ in this area (62\% of the total area) and by the generally small sizes of landslides in this area (the total number of unstable cells corresponds to 35500 square meters, or $\sim 0.33 \%$ of the entire area).

False positives (overprediction of landslide areas) were present in the results of all of the approaches and generally corresponded to:

1. Areas with higher slope angles. These zones are especially visible in the SHALSTAB model, where, if $\tan \theta$ equals or exceeds $\tan \theta$, slope instability will occur even under dry conditions.

2. Areas corresponding to south-facing slopes. Due to the different degrees of insolation, the initial saturation conditions of the soils were different at the beginning of the April 2009 event on south- and north-facing slopes.

3. Areas with vegetation with root systems that contribute to soil strength by providing an additional cohesion
Table 6. Distribution of shallow landslide source areas in relation to April 2009 potential solar radiation.

\begin{tabular}{lll}
\hline $\begin{array}{l}\text { April 2009 } \\
\text { solar radiation } \\
\mathrm{kW} \mathrm{m}^{-2}\end{array}$ & $\begin{array}{l}\text { Area 1 } \\
\%\end{array}$ & $\begin{array}{l}\text { Area 2 } \\
\%\end{array}$ \\
\hline $66.2-87.5$ & 18.81 & 13.29 \\
$87.5-98.9$ & 27.8 & 32.31 \\
$98.9-110.2$ & 22.83 & 28.63 \\
$110.2-121.6$ & 17.56 & 14.93 \\
$121.6-132.9$ & 13 & 9 \\
$132.9-137.3$ & 0 & 1.84 \\
\hline
\end{tabular}

component (e.g., old woodland areas), which is difficult to quantify.

The different conditions described in points (2) and (3) are generally not taken into account in the studied models.

Figure 10 shows the cumulative potential global solar radiation in April 2009 and the safety factor computed by TRIGRS. It clearly appears that landslides are more common in the north-facing slopes, characterized by a minor amount of incident solar radiation. Table 6 shows how the triggering areas are more frequent in zones with lower insolation: in fact, about $70 \%$ of unstable cells in the area 1 are located in the three classes of lower insolation while this value increases to $74 \%$ in the area 2.

The high insolation in some areas may have affected the degree of saturation of shallow soils and may have lowered the water table. Looking at the safety factor map of the same area computed by TRIGRS, it is clear that most of the source areas corresponding to the false positives predicted by the model are located within areas of the greatest insolation.

A relatively high number of false negatives were related to shallow landslides triggered by anthropogenic activities, such as road use and construction, which have not been incorporated into the physically based models, as previously explained (Fig. 9).

\section{Conclusions}

Different physically based models were used to obtain a shallow landslide susceptibility map of an area in the northern 
Apennines where landslides are the cause of a large amount of damage to infrastructure and agriculture. The methods were applied to two contiguous sites with the same geological context but with different land cover, which results in different typologies and sizes of shallow landslides. In area 1, most landslides are translational and have complex (with an important translational component) movements that develop in abandoned vineyards where the natural surface drainage network disappears due to previous agricultural activities and where the maintenance of the land is very poor. In area 2 , where land cover is represented by vineyards with rows parallel to the maximum slope gradient, the shallow landslides consist of rotational-translational slides of smaller dimensions induced by anthropogenic activities (road use and agricultural activities). Although the physically based models do not take land cover into consideration directly, the hydrologic model of the area is conditioned by agricultural practices and roads. Despite this difference, this study demonstrates that, although the four physically based models assume different hydrological models, they have a similar degree of success in the prediction of shallow landslide source areas.

The following considerations can be made:

- TRIGRS, SLIP and SINMAP were used to model the source areas of shallow landslides for a specific event (the April 2009 event). Heterogeneity was accounted for by allowing material properties and other input values to vary from grid to grid.

- SHALSTAB provides the spatial distribution of critical rainfall, which determines the potential for shallow landslide initiation.

- The SINMAP model furnishes more unrealistic scenarios than the other models.

- The simplified formulation of the SLIP model allows a "dynamic" (i.e., time-varying) stability analysis on territory scale with a very low time-consuming computation, based on hourly rainfall distribution, as already highlighted in Montrasio et al. (2011).

Physically based models are useful for shallow landslide susceptibility assessment at the regional scale, and they can be used as "background knowledge" in the PTCP (Provincial Territorial Coordination Plan), which provides information regarding the areas where landslides are likely to be initiated and will be useful in planning long-term risk reduction strategies.

The comparison between the different methods aided in the identification of the most important factors affecting the incidence of shallow landslides in the study area, namely anthropogenic activities (road cutting and, in particular, vineyard-related activities) and solar radiation. These factors are not taken into account in the commonly used approaches, resulting in an overprediction of shallow landslide source areas.
In the light of what has been evidenced in this study, the authors intend to enhance the SLIP model in order to take into account both land use and solar radiation.

Acknowledgements. This study was possible due to the financial support provided by CIMA Foundation (Savona, Italy) and by the Department of National Civil Protection.

The landslide data were obtained through research projects funded by the Pavia Province and Rotary Club Oltrepo Pavese. The aerial photograph from 18 May 2009, was taken by Rossi s.r.l. (Brescia).

The authors wish to thank the anonymous reviewers for their suggestions and contribution to the work.

Edited by: S. Lorito

Reviewed by: two anonymous referees

\section{References}

Apip, K., Takara, K., Yamashiki, Y., Sassa, K, Ibrahim, A. B., and Fukuoka, H.: A distributed hydrological-geotechnical model using satellite-derived rainfall estimates for shallow landslide prediction system at a catchment scale, Landslides, 7, 237-258, 2010.

Arnone, E., Noto, L. V., Lepore, C,. and Bras, R. L.: Physicallybased and distributed approach to analyze rainfall-triggered landslides at watershed scale, Geomorphology, 133, 3-4, 121-131, 2011.

Bai, S. B., Wang, J., LÜ, G. N., Zhou, P. G., Hou, S. S., and Xu, S. N.: GIS-based and data-driven bivariate landslide-susceptibility mapping in the three gorges area, Pedosphere 19, 14-20, 2009.

Baum, R. L. and Godt, J. W.: Early warning of rainfall-induced shallow landslides and debris flows in the USA, Landslides 7, 259272, 2010.

Baum, R. L., Savage, W. Z., and Godt, J. W.: TRIGRS - A FORTRAN program for transient rainfall infiltration and grid-based regional slope stability analysis, version 2.0, U.S. Geological Survey Open-File Report 2008-1159, 75 pp., 2008.

Begueria, S.: Changes in land cover and shallow landslide activity: A case study in the Spanish Pyrenees, Geomorphology, 74, 196206, 2006a.

Begueria, S.: Validation and evaluation of predictive models in hazard assessment and risk management, Nat. Hazards, 37, 315329, 2006b.

Beven, K. J. and Kirby, M. J.: A physically based variable contributing area model of basin hydrology, Hydrol. Sci. Bull, 24, 43-69, 1979.

Campus, S., Forlati, F., Sarri, H., and Scavia, C.: Shallow landslides hazard assessment based on multidisciplinary studies, 14th Southeast Asian Conference, Hong Kong, 10-14 December, 2001.

Carrara, A., Cardinali, M., Detti, R., Guzzetti, F., Pasqui, V., and Reichenbach, P.: GIS techniques and statistical models in evaluating landslide hazard, Earth Surf. Proc. Land., 16, 427-445, 1991.

Cervi, F., Berti, M., Borgatti, L., Ronchetti, F., Manenti, F., and Corsini, A.: Comparing predictive capability of statistical and deterministic methods for landslides susceptibility mapping: a case 
study in the northern Apennines (Reggio Emilia Province, Italy), Landslides, 7, 433-444, 2010.

Cruden, D. and Varnes, D. J.: Landslide types and processes, Landslides, in: Investigation and Mitigation, edited by: Turner, A. K. and Schuster, R. L., Special Report, 247, 36-75, 1996.

Fredlund, D. G., Xing, A., Fredlund, M. D., and Barbour, S. L.: The relationship of the unsaturated soil shear strength to the soilwater characteristic curve, Canadian Geotechn. J., 33-3, 440448, 1996

Godt, J. W., Baum, R. L., Savage, W. Z., Salciarini, D., Schulz, W. H., and Harp, E. L.: Transient deterministic shallow landslide modeling: requirements for susceptibility and hazard assessments in a GIS framework, Eng. Geol., 102, 214-226, $2008 \mathrm{a}$.

Godt, J. W., Schulz, W. H., Baum, R. L., and Savage, W. Z.: Modeling rainfall conditions for shallow landsliding in Seattle, Washington, Rev. Eng. Geol., 20, 137-152, 2008b.

Iverson, R. M.: Landslide triggering by rain infiltration, Water Resour. Res., 36, 1897-1910, 2000.

Kim, D., Im, S., Lee, S. H, Hong, Y., and Cha, K. S: Predicting the rainfall-triggered landslides in a forested mountain region using TRIGRS model, J. Mountain Sci., 7, 83-91, doi:10.1007/s11629010-1072-9, 2010.

Lancellotta, R.: Geotecnica, Zanichelli, 481 pp., 2004.

Li, C., Ma, T., Sun, L., Li, W., and Zheng, A.: Application and verification of a fractal approach to landslide susceptibility mapping, Nat. Hazards, 61, 169-185, 2012.

Liao, Z., Hong, Y., Kirschbaum, D., Adler, R., Gourley, J. J., and Wooten, R.: Evaluation of TRIGRS (Transient Rainfall Infiltration and Grid-based Regional Slope-Stability Analysis)'s predictive skill for Hurricane-triggered landslides: A Case study in Macon county, North Carolina, Nat. Hazards, 43, 245-256, 2011.

Lu, N., Wu, B., and Tan, C. P.: Tensile strength characteristics of unsaturated sands, J. Geotechn. Geoenviron. Eng., 133, 144-154, 2007.

Lu, N. and Godt, J. W.: Infinite-slope stability under steady unsaturated seepage conditions, Water Resour. Res., 44, W11404, doi:10.1029/2008WR006976, 2008.

Meisina, C. and Scarabelli, S.: A comparative analysis of terrain stability models for predicting shallow landslides in colluvial soils, Geomorphology 87, 207-223, 2007.

Montgomery, D. R. and Dietrich, W. E.: A physically based model for the topographic control of shallow landsliding, Water Resour. Res., 30, 1153-1171, 1994.

Montrasio, L.: Stability analysis of soil slip, in: Proc. of International Conf. "Risk 2000", edited by: Brebbia, C. A., Wit Press, Southampton, 2000.

Montrasio, L. and Valentino, R.: Experimental analysis and modeling of shallow landslides, Landslides 4, 291-296, 2007.

Montrasio, L. and Valentino, R.: A model for triggering mechanisms of shallow 1 andslides, Nat. Hazards Earth Syst. Sci., 8, 1149-1159, doi:10.5194/nhess-8-1149-2008, 2008.

Montrasio, L., Valentino, R., and Quintavalla, C.: Estimation of the degree of saturation of shallow soils from satellite observations to model soil slips occurred in Emilia Romagna Region of Northern Italy, Int. J. Geosci., 1, 58-65, 2010.
Montrasio, L., Valentino, R., and Losi, G. L.: Towards a real-time susceptibility assessment of rainfall-induced shallow landslides on a regional scale, Nat. Hazards Earth Syst. Sci., 11, 1927-1947, doi:10.5194/nhess-11-1927-2011, 2011.

Montrasio, L., Valentino, R., and Losi, G. L.: Shallow landslides triggered by rainfalls: modeling of some case histories in the Reggiano Apennine (Emilia Romagna Region, Northern Italy), Nat. Hazards, 60, 1231-1254, 2012.

Nova, R.: Soil mechanics, Wiley-ISTE, London, 399 pp., 2010.

Pack, R. T., Tarboton, D. G., and Goodwin, C. G.: SINMAP 2.0 - A Stability Index Approach to Terrain Stability Hazard Mapping, User's Manual. Produced in ArcView Avenue and C++ for Forest Renewal B.C. under Research Contract No: PA97537-0RE, http://digitalcommons.usu.edu/cgi/viewcontent. cgi?article=1015\&context=cee_facpub, 1999.

Qiu, C., Esaki, T., Xie, M., Mitani, Y., and Wang, C.: Spatiotemporal estimation of shallow landslide hazard triggered by rainfall using a three-dimensional model, Environ. Geol., 52, 1569-1579, 2007.

Salciarini, D., Godt, J. W., Savage, W. Z., Conversini, P., Baum, R. L., and Michael, J. A.: Modeling regional initiation of rainfallinduced shallow landslides in the eastern Umbria Region of central Italy, Landslides, 3, 181-194, 2006.

Salciarini, D., Godt, J. W., Savage, W. Z., Baum, R. L., and Conversini, P.: Modeling landslide recurrence in Seattle, Washington, USA, Eng. Geol., 102, 227-237, 2008.

Schmidt, J., Turek, G., Clark, M. P., Uddstrom, M., and Dymond, J. R.: Probabilistic forecasting of shallow, rainfall-triggered landslides using real-time numerical weather predictions, Nat. Hazards Earth Syst. Sci., 8, 349-357, doi:10.5194/nhess-8-3492008, 2008.

Simoni, S., Zanotti, F., Bertoldi, G., and Rigon, R.: Modelling the probability of occurrence of shallow landslides and channelized debris flows using GEOtop-FS, Hydrolog. Process., 22, 532-545, 2008.

Tarboton, G. D.: A new method for the determination of flow directions and upslope areas in grid digital elevation models, Water Resour. Res., 33, 309-319, 1997.

Thornthwaite, C. W. and Mather, J. R.: Instructions and tables for computing potential evapotranspiration and the water balance, Climatology, 10, 3, 185-311, 1957.

Vercesi, P. and Scagni, G.: Osservazioni sui depositi conglomeratici dello sperone collinare di Stradella. Rend. Soc. Geol. It., 7, 23 26, 1984.

Vieira, B. C., Fernandes, N. F., and Filho, O. A.: Shallow landslide prediction in the Serra do Mar, São Paulo, Brazil, Nat. Hazards Earth Syst. Sci., 10, 1829-1837, doi:10.5194/nhess-101829-2010, 2010.

Wu, W. and Sidle, R. C.: A distributed slope stability model for steep forested hillslopes, Water Resour. Res., 31, 2097-2110, 1995. 